\title{
Studying the Relation between the Transformational Leadership and Employees Empowerment (Case Study of Bank Passargad of Iran)
}

\author{
Soudabe Salek ${ }^{1} \&$ Fatemeh Khoeini ${ }^{2}$ \\ ${ }^{1}$ Department of Business Management, Firoozkook Branch, Islamic Azad university, Firoozkooh ,Iran \\ ${ }^{2}$ Academic staff in faculty of management Islamic Azad University, Firoozkooh, Iran \\ Correspondence: Dr Fatemeh Khoeini, Academic staff in faculty of management Islamic Azad University, \\ Firoozkooh, Iran. E-mail: fa.khoyeeni@yahoo.com
}

Received: October 18, 2016

Accepted: November 1, 2016

Online Published: November 28, 2016

doi:10.5539/mas.v11n2p61

URL: http://dx.doi.org/10.5539/mas.v11n2p61

\begin{abstract}
The aim of this research is to investigate relationship between transformational leadership and employee's empowerment working in Pasargad bank. Population under the study consists of all staff employees of Pasargad bank equals to 535 individuals. Research sample is of 204 individuals who have been selected by simple random sampling method. Instruments used for measuring the study include two standard questionnaires for transformational leadership and empowerment which enjoy considered validity and Stability. For analyzing research data, Spearman's rank correlation coefficient has been used and results indicated that there is a meaningful relationship between Idealized features, Idealized behavior, Intellectual Stimulation, Inspirational Motivation, Individualized Consideration and employee's empowerment. In other words, there is relationship between transformational leadership and employee's empowerment.
\end{abstract}

Keywords: transformational leadership, empowerment, idealized features and behavior, intellectual stimulation, inspirational motivation, individualized consideration

\section{Introduction}

\subsection{Description of the Problem}

Banks and Banking today to one of the activities of human life has become inseparable and can rarely find someone who constantly has to deal with one of banking services. Bankers also in other fields such as the passage of time have undergone tremendous changes and extensive services offered to customers this way. Banks seek to compete with its rivals every day a new range of services offered to their customers and attract new customers at any price has become one of the main goals of the banks. In the last two decades with the increasing number of banks and credit institutions activity, competition in the industry as a whole has changed. What is significant in this area, the same type of services and products as one of the most competitive areas of business. Because of the similarity of services and lack of innovation in the form of massive, what can distinguish a bank from other banks, the difference in the quantity and quality of service (Soleymani \& Akbari, 1391). Classically primary responsibility for process improvement in service organizations, realized the staff. The employees' organizations deal with clients on a daily basis and constantly and to have a successful leading organization must first of all attempt to increase the ability of staff to pursue those objectives be achieved organization (Ekhlasi, 1391). Efforts to increase the ability of staff to provide the services that are referred to as the empowerment of the key topics in management is taken into account. Empowerment in its broadest sense and to strengthen the ability of the human resources in order to achieve the objectives of the organization, a new thread is not included. This is a different concept seen in the history of the formation of human resources management (Abtahi \& Ayesi, 1390). New approaches to human resource management view employees as a competitive advantage inimitable. And it is believed that empowered human resources in addition to the Daily performance of employees, intellectual power and creativity of the staff will be managed (Heidari et al., 1388). Given the importance of empowering the organization's human resources personnel to identify factors affecting empowerment is very important. Researchers Opinions about the determinants of empowerment due to the extent of factors affecting human resource performance is very versatile and every researcher explains the aspect of these factors. In a comprehensive perspective on the topic of empowerment influencing factors can be divided into three general categories: individual, organizational factors and strategic factors divided (Jazani \& Rostami, 
1390). The study of the different factors affecting empowerment has focused on leadership style. As a result of the actions of managers' leadership style on other organizational factors such as labor relations, training, and evaluation in the organization. Since the emergence of early leadership theories are different opinions as well as personal characteristics, behavioral styles, contingency, documentary, alternative and transformational leadership provided by experts. In this study the most effective and most widely studied and transformational leadership styles, the style has been attempted to be answered the following questions:

- Is there a relationship between transformational leadership and employee empowerment?

- Is there a relationship between the characteristics of the ideal employee empowerment?

- Is there a relationship between employee empowerment behaviors Armani?

- Is there a relationship between intellectual stimulation to empower employees?

- Is there a relationship between motivation and inspiration to empower employees?

- Is there a relationship between the individual aspects of employee empowerment?

With regard to questions intended conceptual model was as follows:

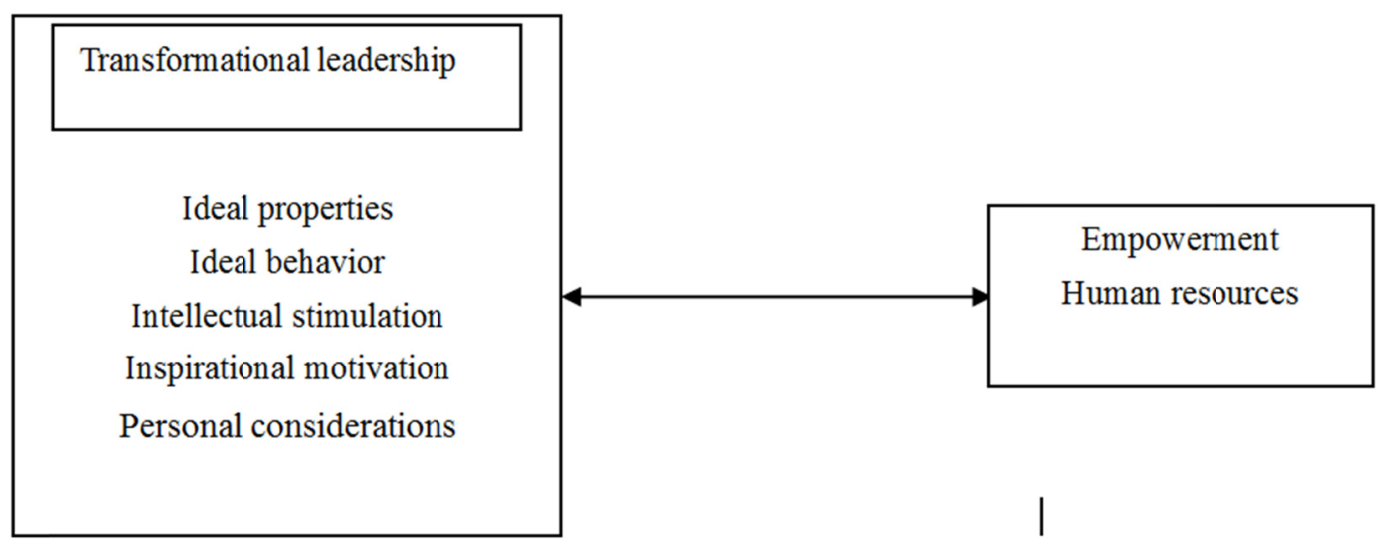

Figure 1. The conceptual model

\subsection{Methodology}

Scientific research can be divided based on two foundations, the purpose and method. The purpose of this study can be considered an applied research. Also in terms of methodology, this study is a descriptive and correlational study is taken into account (Edwards et al., 1391).

The research community all have Pasargad Bank staff that the number of people equal to 535 people. The number of samples needed for a community of 535 people using Morgan table 226 is obtained. In this study, a sample of random probability sampling method used (Duas, 1389). Questionnaire was tried in this study to increase the reliability of standard questionnaires that have been used by other researchers, is used. In order to determine the validity, the final questionnaire was given to supervisors and other experts and then commented and resolve ambiguities, was approved. Used to calculate the reliability of the questionnaire, 20 questionnaires were completed for Pretest and using SPSS software transformational leadership and calculated Cronbach alpha equal to 0.856 and 0.839 respectively for equal empowerment questionnaire that due to higher 0.7 can be argued that these numbers are research questionnaires of reliability.

\section{Concepts, Opinions and Theoretical Foundations}

\subsection{Transformational Leadership: Definitions and Concepts Related}

The roots of transformational leadership paradigm in studies carried out by Machiavelli go back to the sixteenth century. The characteristics and behavior of leaders to develop leadership theory in the study of feudal England. In the new era of transformational leadership for the first time by Danton (1973) was used. The theory of transformational leadership by Burns In order to distinguish between those leaders and motivational strong relationships with subordinates and followers of Cruelty And those of them who are widely focused on exchange or interaction to make the results are there (Duckett \& Macfarlane, 2003).

Burns drew attention to the nature of the relationship between leaders and followers interact. He has led studies 
on the dynamics of conflict and the deliberate collective goals and the importance of the moral basis of leaders and followers brought real change And then led two proposed models: Transactional and transformational (Magliocca \& Christakis, 2001).

Bass and Avolio developed the Burns concept of leadership and make a concept of transformational leadership value. Bass and Avolio believe that transformational leadership occurs when the leader of interests to promote and develop employees, Target groups for the mission to create awareness and acceptance and staff to see beyond their own interests to arouse interest groups (Stone, 2004). Definition of transformational leadership are numerous. Some of these definitions are as follows:

Transformational leadership and followers enables them to function beyond expectations and comply with the targets collectively rather than self-interest motivates

Emphasize the need for transformational leadership, values and attitudes of the followers of followers attempted to create ethical responsibility. Transformational leadership by creating eye in new ideas and enthusiasm salinity build trust among managers and employees in order to modify the organizations operate and promising development and improve the performance of the organization. (Yazdanshenas and Jamshidian, 1387).

Transformational Leadership is a process of moral and spiritual conscious that the same patterns of power relations between leaders and followers to achieve a collective goal or builds real change (Magliocca \& Christakis, 2001).

Transformational Leadership optimism intelligence attractions were many other personal ability to work to promote the ideals of others are focused on individuals and organizations to deliver higher performance (Manning \& Curtis, 2013)

Transformational leadership, which is part of the new paradigm of leadership and represents the process of changing and variable, and the values, ethics and long-term goals associated attributes (Keyvanloo et al., 1390).

In most constructive aspects of transformational leadership theories presented for it is divided into four main components considering that one of them is divided into two sub-factors they can also be considered five factors. These four factors are: idealized influence, inspirational motivation, intellectual stimulation and individualized consideration.

- Charisma or idealized influence:

The first factor is called transformational leadership charisma or idealized influence becomes strong leaders described as a model act for followers. If you are a transformational leadership, a sense of respect, admiration and loyalty among their followers will create a strong commitment to achieve the mission and the importance of having organizations will be emphasized. The operating principle charisma describe people who encourage others to follow his vision. Charisma describes exactly depends on the influence and motivate their followers and create a vision and insight that as one of the key elements is transformational leadership. House and many other theorists such as leadership charisma as an essential element for transformational leadership has been defined (Mooghali, 1382). Makes favorable influence of role models and leaders as role models for their followers. In some of the followers of the leader charisma or influence by the two components of leadership traits and his behavior is known. In other words, the ideal of the ideal characteristics and behaviors ideals.

- Motivation and inspiration:

Features inspiring leaders that the expectations beyond initial expectations put before followers and by stimulating their emotions to realize this shared vision to fulfill expectations and keep walking. Increased commitment normally done by involving members in outlining future prospects. Moreover, motivate and raise the motivation of followers by appealing to their emotions are done. It should be noted that the emphasis on emotion and motivation is internal motivation and inspiration rather than daily exchanges between leaders and followers (Moriano \& Molero, 2011).

- Intellectual stimulation:

In other words motivate followers by leaders to discover new solutions and new thinking about solving organizational problems is done by the followers. This is achieved when leaders mobilize the initiative and creativity of constructive help to achieve (García-Morales et al, 2012).

- Personal considerations:

According to others is another important aspect of transformational leadership. To achieve this level of leadership to his followers in order to meet their desired service and to develop the potential of people tries. 
Time to realize is that development-oriented support the leader needs followers far enough attention is paid in order to achieve further growth and any supplement hesitate guidance and support in this regard. On this basis, the duties of the leader's followers who in many ways is ensuring their growth.

\subsection{Empowerment: Definitions and Concepts Related}

Empowering employees is one of the most effective techniques to increase employee productivity and the efficient use of capacities and capabilities of individual and group them in line with organizational goals. Empowerment is the process of enabling people of a society or a social system. (Aghlmand and Akbari, 1384).

Empowerment, not a new concept. The concept for the new academic resource management across different states. In 1930, McGregor's Theory Y provided that he believed that the formal aspects of the organization's management relies, cannot develop or improve management organizations to act; Because in this way the place for taking advantage of the capabilities of human resources And there paving the way for human development (Abtahi \& Abesy, 1391). Also in the 1950s, the scientific literature is full of prescriptive management that managers should be friendly towards their employees (human relations) in the 1960s, the managers had recommended that staff be sensitive to the needs and motives (James, 2011). In 1988, Conger \& Kanungo said first operational definition of empowerment. According to the researchers, to be able to analyze the concept of empowerment in the management contract First of structures of power and control that the term of it is due to be examined. From their perspective, since the power and control in management texts were used in two different ways, empowerment should be considered in two different ways. Authors' empowerment as a motivational and communication structures are examined (Conger \& Kanungo, 1988). Empowerment has several definitions. In some definitions of empowerment has been emphasized only certain aspects for this reason, ever perfect, comprehensive and clear that everyone agrees on it have been presented. Some of the definitions provided for empowerment are as follows:

From the perspective of Whetten \& Cameron the release of internal force empowering people to achieve amazing results.

According to Bowen and Lawler Empowerment that comes when there is power, information, knowledge and bonuses to be distributed in the organization and is zero if one of the four elements of empowerment will also be zero (Eskandari, 1390).

Empowering the development process, which enhances the ability of employees to solve problems and improvement of political vision and social workers to enable them to identify environmental factors are under your control. (Aghayari, 1386)

Foy empower decision-making power distributed to people who do not have it defined. According to him, empower an entrepreneurial approach that is essential to provide employees to pay their own decisions (Moqimi, 1389).

Lockchen call empowerment process the status changing of the staff does what they are told to do to what is needed to do (Aghayari, 1386).

Blanchard prepares the conditions in order to supply the best intellectual resources in every area of the organization's performance to the enabling of the calls. In his opinion this is the best goal of empowering employees with best practices exert the most influence. (Hadavand \& Sadeghian, 1386)

According to the Schoell, but empowerment is to grant more authority to staff to make decisions without initially be supervised and controlled by higher levels of management (Schoell et al., 2010).

In summary it can be said that most definitions of empowerment on this point agree that the key element of empowerment, giving freedom to employees in connection with activities. In most definitions of the following five components is referred to as the five dimensions of empowerment:

- Competence or self-efficacy

Merit the degree to which a person can do the job with skill points. When people are empowered, and feel a sense of self-efficacy capabilities and expertise necessary to carry out their work successfully. (Klidas, 2002).

- Self-determination (autonomy)

Empower people about their sense of responsibility and ownership of their activities. They are able to do their own initiatives, to take independent decisions and new ideas put to the test. These people feel that their activities rather than predetermined and controlled from the outside, they see themselves as the center control. From the perspective of management variety of schools, freedom or autonomy must be appropriate to the type of work and 
responsibility that rests with tomorrow between discretionary powers granted to individual must be balance and proportionality (Afkari \& Ghanbari, 1391).

- Feel the effectiveness of

Gomez believes that a sense of efficacy, the belief person within a specified period of time the ability to create change (Gomez \& Rosen, 2001). Empowering people feel personal control over their results. it can be controlled sources Krd.nha feel active control, which allows them to align their environment with their demands. Unlike passive control where environmental demands in line with the wishes of the people. Those who feel they are being effective, instead of trying to conduct a reaction against the environment, control over what they see, maintain (Sasiadek, 2006)

- Feel the effectiveness of

Gomez believes that a sense of efficacy, the belief person within a specified period of time the ability to create change (Gomez \& Rosen, 2001). Empowering people feel personal control over their results. Where resources can be controlled. They feel active control, which allows them to align their environment with their demands. Unlike passive control where environmental demands in line with the wishes of the people. Those who feel they are being effective, instead of trying to conduct a reaction against the environment, control over what they see, maintain (Sasiadek, 2006)

- Meaningful

By means of the fit between the requirements of working with beliefs, values and behaviors of the person refers. Regardless of organizational constraints, people tend to strive towards goals that they have a concept. Meaningful are capable people. These people are more innovative, higher-level, more effective and more efficient than those that are personally meaningful in terms of jobs have lower rates (Greasily ET all. 2004).

- Sense of trust in others

Empowering people are confident that they will be treated fairly and equally. They are confident that even in the hands of the works not harm the final result, but also justice.

\section{Conclusions and Recommendations}

According to data obtained positive relationship between transformational leadership and employee empowerment there is a significant and increasing employee empowerment is the use of transformational leadership. This research is in line with Len and Chong (2015) in which it is recognized that transformational leadership is significantly related to psychological empowerment of employees. The results of the two researchers have shown that in individual and group level employees' personal and group identity, the relationship between transformational leadership and employee performance and affects empowerment. According to the results, the following suggestions are offered:

Despite confirming the relationship between transformational leadership and empowerment is suggested that And written instructions to create and strengthen a sense of responsibility among employees, with an emphasis on the needs, values and attitudes developed by And then by the General Agreement on internal systems were available to all employees And training and control to verify the objectives of the program over the years to be considered. It is suggested with the capacity of organizations and companies active in the field of educational topics Special courses for middle managers and senior management held So that education leaders in organizations that act as powerful models for their followers And a sense of respect, admiration and loyalty among them than their own. Due to confirm the effects of the ideal behaviors of managers on the staff empowerment, Provide practical steps for actions approved by the Directors And also offer financial rewards to managers who have scores to assess performance in this field are appropriate in this field. Among the employees in providing quality services to the customers. To create this internal space of supplies is suggested. Finally, in the area of employee empowerment is personal considerations. It is suggested that when evaluating the performance of branch managers on how their communications with employees through communication and how to manage them effectively be emphasized personal. Also recommended Offers a comprehensive program for obtaining of staff in the field to run around and using the levers to encourage employees be encouraged and in this regard to research and submit proposals. Finally, in the area of employee empowerment is personal considerations. It is suggested that when evaluating the performance of branch managers on their communications with employees and how to manage them effectively be emphasized by communicating personal. Having the feeling that the behavior of others is stable and reliable and information can be safely viewed and that the promises will be all part of the formation of people's sense of empowerment. In many cases, individuals are empowered with powerful individuals, they do not show friendliness and flexibility, again, in 
such a way to maintain a sense of personal trust (Higgs, 2003).

\section{Analysis of Findings}

Of the 226 questionnaires, 22 of them were excluded because of incomplete analysis process. Finally, 204 questionnaires were analyzed. In this process of the study of the study, the KS test was used for data normalization. The following table shows the results of this test for all the components of the study.

Table 1. Normal distribution of data for variables

\begin{tabular}{cccc}
\hline Significance level (Sig) & Kolmogorov Smirnov & Number & \\
\hline 0.001 & 0.137 & 204 & Ideal properties \\
0.000 & 0.146 & 204 & Ideal behavior \\
0.012 & 0.111 & 204 & Intellectual stimulation \\
0.003 & 0.138 & 204 & Inspirational motivation \\
0.000 & 0.153 & 204 & Personal considerations \\
0.025 & 0.081 & 204 & Transformational Leadership \\
0.033 & 0.079 & 204 & Empowerment \\
\hline
\end{tabular}

Given that a significant level achieved for all components is smaller than 0.05 assuming $\mathrm{H} 0$ is rejected.

In other words, it can be concluded that the data distribution is not normal.

According to the non-normal distribution of data, in this study, the relationship between variables, Spearman correlation test was used. If you obtained Sig is smaller than 0.05, assuming investigate the relationship between the two variables is confirmed. But if greater than 0.05 indicates a significant level of correlation between these two variables were not significant and linear relationship with each other. In this test, to show the intensity of the relationship of the correlation coefficient is a number between -1 and 1 that is used. Whatever the number is zero distance is greater than the value of the relationship between two variables (believers and active omniscience, 1390).

Table 2. The results of the relationship between transformational leadership and empowerment and its components

\begin{tabular}{|c|c|c|c|}
\hline Spearman & $\begin{array}{l}\text { SL } \\
\text { (Sig) }\end{array}$ & $\begin{array}{l}\text { Confidence } \\
\text { Level }\end{array}$ & \\
\hline$\overline{0.562}$ & 0.000 & $\% 95$ & $\begin{array}{l}\text { There is a significant relationship between transformational leadership and } \\
\text { employee empowerment }\end{array}$ \\
\hline 0.383 & 0.000 & $\% 95$ & $\begin{array}{l}\text { There is a significant relationship between the characteristics of the ideal } \\
\text { employee empowerment. }\end{array}$ \\
\hline 0.452 & 0.000 & $\% 95$ & $\begin{array}{l}\text { There is a significant relationship between employee empowerment and } \\
\text { organizational behavior. }\end{array}$ \\
\hline 0.545 & 0.000 & $\% 95$ & $\begin{array}{l}\text { There is a significant relationship between mental persuasions with } \\
\text { empowerment. }\end{array}$ \\
\hline 0.437 & 0.000 & $\% 95$ & $\begin{array}{l}\text { There is a significant relationship between motivation and inspiration with } \\
\text { empowerment. }\end{array}$ \\
\hline 0.479 & 0.000 & $\% 95$ & $\begin{array}{l}\text { There is a significant relationship between individual considerations with } \\
\text { empowerment. }\end{array}$ \\
\hline
\end{tabular}

According to the data, obtained a significance level of less than 0.05 . Therefore, the hypothesis H0 be rejected. In other words $95 \%$ said that between transformational leadership and employee empowerment and its components there is a significant relationship. Between 0.383 and 0.562 correlation coefficient between variables was obtained. The positive correlation coefficient means that the relationship is positive and means that 
the use of transformational leadership is increased employee empowerment. Also, due to the correlation coefficient can be said is that this strong relationship.

\section{Acknowdegement}

In this thesis, it is the highest time which we have seized the opportunity to offer our most genuine and profound words of gratitude to many people to whom we owe the accomplishment of this research. We want specifically apprieciate our honorable thesis advisor, Dr. Fatemeh Khoeini, Academic staff in faculty of management Islamic Azad University, Firoozkooh, who patiently help us through every line of this thesis and provided us with many insightful comments and invaluable suggestions. We would also like to extend our sincere appreciation and gratitude to Chairman of Firoozkooh Bank Pasargad who has assisted us in this thesis.

\section{References}

Abtahi, H., \& Abassi, S. (1391). Employees empowerment, Publisher of Research and Management Training Institute of the Ministry of Energy.

Alaghemand, S., \& Akbari, F. (1384). Empowerment: A managerial strategy for achieving sustainable development. Tehran, Third Management International Conference.

Conger, J. A., \& Kanungo, R. N. (2002). The empowerment process: integrating theory and practice. Academy of Management Review, 13(3), 471-482.

Dewas, D. E. (1389). A survey in social researches, translated by Hoshang Nayebi, Tehran, Ney Publications.

Duckett, H., \& Macfarlane, E. (2003). Emotional intelligence and transformational leadership in retailing. Leadership \& Organization Development Journal, 24, 309-317.

Edwards, J. Y., et al. (1391). Survey research, action guide", translated by: Mohammad Arabi, Dawod Izadi, Tehran, Cultural Research Bureau.

Ekhlasi, A. (1391). Services Marketing, Tehran, Scientific publications.

Elkins, T., \& Keller, R. T. (2013). Leadership in research and development organizations: A literature review and conceptual framework; The Leadership Quarterly, 14.

Eskandari, M. (1390). Design and explain of managers empowerment pattern. Public management doctoral dissertation, Tehran University.

García-Morales, V. J., Jimenez, B. M. M., \& Gutierrez, G. L. (2012). Transformational leadership influence on organizational performance through organizational learning and innovation. Journal of Business Research, $65,40-50$

Gomez, C., \& Rosen, B. (2001). The leaded- member Exchange as a link between managerial trust and employee. Empowerment. Group and organization management".

Greasily, K., et al. (2004). Employee participation of empowerment. Employee Relation, 27(4), 354-368.

Hadavand, S., \& Sadeghian, S. (1386). The effective structures in empowering of the employees, Tadbir magazine, 180.

Heydari, H., Seyyed, J., Reza, S. S. (1388). The study of the factors affecting on the empowerment of human resources in the case study service in the banking system. Public Administration Journal, 2.

Higgs, M. (2003). How can we make sense of leadership in the 21st century, Leadership and Organization Development Journal, 24(5), 271-284.

Jazani, N., Rostami, A. (1390). Design and Empowerment strategic model development of the human resources in knowledge-based organizations, organizational resources management researches quarterly, 1(3).

Kark, R. (2004). The transformational leader. who is (s)he? A feminist perspective. Journal of Organizational Change Management, 17(2).

Keivanloo, F., Koshan, M., Seyyed, A. M. (1390). The relationship between emotional intelligence and leadership style. Sabzevar University of Medical Sciences, 8(1).

Klidas, A. K. (2002). Employee empowerment in the European cultural context: findings fromindustry. PhD, thesis, Amsterdam: Rosenberg Publishers.

Lan, X. M., \& Chong, W. Y. (2015). The Mediating Role of Psychological Empowerment between Transformational Leadership and Employee Work Attitudes. Social and Behavioral Sciences, 172(27), 184-191. 
Magliocca, L. A., \& Christakis, A. N. (2001). Creating transforming leadership for organizational change: the cogniscope system approach. System Research and Behavioral Science, 18.

Manning, G., Curtis, M. K. (2013). The art of leadership, New York : Mc graw Hill higher education

Moghimi, S. M. (1389). Entrepreneurship in public organizations. Tehran,Entrepreneurship Center publication of Tehran University.

Momeni, M., \& Ghayomi, A. (1390). The statistical data analysis using SPSS, Tehran.

Mooghali, A. (1382). The design of transformational leadership style in Iran administration organization. Management Knowledge Journal, 62.

Moriano, J. A., \& Molero, F. (2011). The influence of transformational leadership and organizational identification on entrepreneurship. Intentional Entrepreneurship Management Journal, 12(3).

Poor, A., Nasroallah, Ghanbari, A. (1391). Empowerment mechanism human resources in the sports organizations management. Iran Studies Journal of Social Development, 4(3).

Sasiadek, S. M (2006). Individual Influence Factors That Impact Employee Empowerment: A Multi case study". Unpublished dissertation capella university.

Schoell, W., Dessler, G., \& Reinecke, J. (2010). Introduction to Business. Allyn \& Bacon: USA.

Soleimani, A., \& Akbari, R. (1391). Banking services marketing, Tehran, Etehad Publications.

Stone, A., Gregory, R., Robert, F., \& Patterson, K. (2004). Transformational Versus Servant Leadership - A Difference in Leader Focus. Leadership and Organization development Journal, 25(4).

Taboli, H. (1391). Tiregar Hedayatoallah, Mozafari, Leila, Mortazavi, Hamid Mehrabi, Fatemeh Far. The study of the relationship between transformational leadership style and employees creativity in public organization of Neyriz city. Innovative and creative journal in Human sciences, 2(1).

Wang, X. H., \& Howell, J. M. (2012). A multilevel study of transformational leadership, identification and follower outcomes. The Leadership Quarterly, 23(5), 775-790.

Yaghobi, N., \& Moghadami, M. (1389). The study of the relationship between transformational leadership and employees organizational citizenship behavior. Change Management Research, 2(4).

Yazdanshenas, R., \& Jamshidian, A. (1381). The role of transformational leadership in change management, Tehran. Sixth International Conference on Management.

\section{Copyrights}

Copyright for this article is retained by the author(s), with first publication rights granted to the journal.

This is an open-access article distributed under the terms and conditions of the Creative Commons Attribution license (http://creativecommons.org/licenses/by/4.0/). 